\title{
PREDIKSI PENYAKIT DEMAM BERDARAH DI PUSKESMAS NGEMPLAK SIMONGAN MENGGUNAKAN ALGORITMA C4.5
}

\author{
${ }^{1}$ Saifur Rohman Cholil, ${ }^{2}$ Aditya Febri Dwijayanto, ${ }^{3}$ Tria Ardianita \\ ${ }^{1,3}$ Program Studi Sistem Informasi, Fakultas Teknologi Informasi dan Komunikasi \\ ${ }^{2}$ Program Studi Teknik Informatika, Fakultas Teknologi Informasi dan Komunikasi \\ Universitas Semarang (USM) \\ Jl. Soekarno Hatta, Tlogosari Kulon, Kec. Pedurungan, Semarang, Indonesia 59160 \\ E-mail:cholil@usm.ac.id, adityafebri3@gmail.com,triaardianita@gmail.com
}

(Diterima: 16 Juni 2020 ,direvisi: 3 Juli 2020, disetujui: 18 Juli 2020)

\begin{abstract}
Dengue Hemorrhagic Fever (DHF) is a disease whose main cause is the flaviviridae virus. This virus can be transmitted through mosquito bites. The spread of this disease is faster in urban areas than in rural areas due to the high population density. Aedes aegypti mosquito is very easy to spread dengue virus from one person to another because it has a domestic nature. The Ministry of Health has collaborated with local health centers in the DHF prevention program. Ngemplak Simongan Health Center is one of the public health centers located in the District of West Semarang that serves a variety of treatments for this type of disease, one of which is a patient with Dengue Hemorrhagic Fever (DHF). C4.5 algorithm is used to predict dengue fever which aims to produce a decision tree. The choice of using Algortima is because it is widely used to describe a pattern / knowledge / information in the form of a decision tree explicitly. Application created using PHP programming language that produces prediction of dengue fever. The test results obtained an accuracy value of $94.44 \%$ so that the application program built can be used correctly.
\end{abstract}

Keywords: c4.5 algorithm, decision tree, dengue hemorrhagic fever

\begin{abstract}
ABSTRAK
Demam Berdarah Dengue (DBD) adalah sebuah penyakit yang penyebab utamanya adalah virus flaviviridae. Virus ini dapat ditularkan melalui gigitan nyamuk. Penyebaran penyakit ini lebih cepat di area perkotaan dibandingkan di area pedesaan karena faktor tingginya kepadatan penduduk. Nyamuk Aedes aegypti sangat mudah menyebarkan virus dengue dari orang satu ke orang lain karena memiliki sifat domestik. Departemen kesehatan telah melakukan kerja sama dengan puskesmas sekitar dalam program penanggulangan penyakit DBD. Puskesmas Ngemplak Simongan merupakan salah satu puskemas yang berada di Kecamatan Semarang Barat yang melayani berbagai macam pengobatan jenis penyakit, salah satunya adalah penderita Demam Berdarah Dengue (DBD). Algoritma C4.5 digunakan untuk prediksi penyakit demam berdarah yang bertujuan menghasilkan sebuah pohon keputusan. Pemilihan penggunaan Algortima ini karena banyak digunakan untuk menggambarkan suatu pola/pengetahuan/informasi dalam bentuk pohon keputusan secara eksplisit. Aplikasi yang dibuat menggunakan bahasa pemrograman PHP yang menghasilkan prediksi penyakit demam berdarah. Hasil pengujian didapatkan nilai akurasi sebesar $94.44 \%$ sehingga aplikasi program yang dibangun dapat digunakan secara benar.
\end{abstract}

Kata Kunci: algoritma c4.5, pohon keputusan, demam berdarah dengue

\section{PENDAHULUAN}

Pesatnya perkembangan ilmu pengetahuan dan teknologi khususnya di bidang teknologi informasi dapat memunculkan suatu inovasi baru untuk menyajikan dan mengelola suatu informasi demi memenuhi kebutuhan informasi. Peranan teknologi pada bidang kesehatan maupun kedokteran telah banyak membantu menolong jiwa manusia dan telah menunjukkan peranan pentingnya. Komputer telah banyak digunakan untuk menganalisis bagian dalam organ tubuh manusia yang sulit dilihat, mencari tahu obat yang tepat, bahkan untuk mendiagnosis penyakit.

Saifur Rohman Cholil dkk: Prediksi Penyakit Demam Berdarah Di Puskesmas Ngemplak Simongan Menggunakan Algoritma C4.5 
Demam Berdarah Dengue (DBD) adalah penyakit yang ditularkan oleh nyamuk lewat gigitannya yang mengandung virus flaviviridae serta dapat menyebabkan kematian. Penyebaran penyakit DBD di area perkotaan lebih cepat dibandingkan di area pedesaan karena faktor tingginya kepadatan penduduk. Nyamuk Aedes aegypti sangat mudah menyebarkan virus dengue dari orang satu ke orang lain karena memiliki sifat domestik. Penanganan program penyakit DBD yang dilakukan oleh pemerintah khususnya Departemen Kesehatan telah melakukan kerja sama dengan semua puskesmas sekitar untuk deteksi dan pengobatan penyakit tersebut.

Puskesmas Ngemplak Simongan merupakan salah satu puskemas yang berada di kecamatan Semarang Barat yang melayani berbagai macam pengobatan jenis penyakit salah satunya adalah penderita Demam Berdarah Dengue (DBD). Puskesmas Ngemplak Simongan merupakan puskesmas yang jumlah pasien penderita DBD terbanyak di kecamatan Semarang Barat. Dimana dalam melakukan pengecekan pasien yang terkena penyakit demam berdarah harus melalui diagnosa terlebih dahulu. Kemudian dilanjutkan dengan pemeriksaan laboratorium jika diperlukan oleh pasien. Tujuan penelitian ini adalah memprediksi penyakit demam beradarah menggunakan algoritma C4.5 dan membuat sistem berbasis web untuk melakukan prediksi penyakit tersebut. Prediksi dilakukan dengan cara mengambil data-data yang sudah ada pada Puskesmas tersebut tentang penyakit DBD yang selanjutnya disebut sebagai data training.

Algoritma C4.5 telah banyak digunakan untuk memprediksi penyakit, diantaranya dari penelitian [1] melakukan prediksi penyakit Rheumatoid Arthritis (RA) dan mempunyai akurasi rata-rata 84\%. Prediksi kelangsungan hidup kanker paru-paru [2] dengan metode SVM, Naïve Bayes dan C4.5, hasil akurasi menunjukkan algoritma C4.5 memiliki kinerja lebih baik dibandingkan yang lain dalam memprediksi kanker paru-paru. Algoritma C4.5 juga digunakan [3] untuk diagnosis turbin angin, deteksi dan diagnosis kesalahan sistem photovoltaic (PV) yang terhubungan dengan jaringan [4] yang mempunyai akurasi pengujian sebesar 99,8\%.

Pohon keputusan algoritma C4.5 digunakan untuk penalaran tegas manajemen tanggap darurat [5], kontruksi kendala otomatis untuk model Mixed-Integer Linear Programming (MILP) dari data [6] dan pengembangan pohon keputusan [7]. Algoritma ini juga digunakan oleh [8] untuk penilaian stabilitas tegangan online dan hasilnya bisa membantu operator sistem menilai status stabilitas tegangan secara real-time.

\section{TINJAUAN PUSTAKA}

\subsection{Data Mining}

Data Mining merupakan serangkaian proses untuk mencari informasi maupun pola yang berupa informasi dari suatu basis data dengan memanfaatkan teknik tertentu [9]. Hasil dari informasi diperoleh dari mengekstraksi dan meganalisis pola data yang ada dalam basis data [10]. Knowledge Dicovery Database (KDD) merupakan metode yang saintifik dalam data mining, karena digunakan untuk mencari informasi maupun pengetahuan baru yang terdapat dalam kumpulan data. Data mining juga merupakan pembelajaran yang memiliki basis induksi karena terdapat proses pembentukan definisi dengan konsep umum dengan cara mengobservasi contoh yang spesifik dari semua konsep yang dipelajari [11]. Data mining sendiri telah banyak digunakan sebagai penelitian, salah satunya pada [12] yang digunakan untuk memprediksi masa studi mahasiswa dengan hasil nilai evaluasi penelitian yang lebih akurat dibandingkan dengan analisa secara manual. Penganalisaan data mining diperlukan sebuah software yang disebut dengan Rapid Miner. Software ini dibuat dengan menggunakan bahasa pemrograman Java serta dapat dijalankan pada sistem operasi apapun. Seperti pada penelitian [13] tentang analisa data hasil keuntungan dengan Rapid Miner yang dapat membantu proses analisis data dengan cepat dan efisien dengan kepastian kemungkinan sekitar $0,59 \%$.

\subsection{Algoritma}

Algoritma merupakan sistem kerja komputer yang digunakan untuk menyusun langkah yang sistematis agar dapat digunakan untuk memecahkan suatu masalah. Algoritma juga bersifat logis dan sistematis karena susunan langkahnya disusun secara tertulis dan berurutan. Algoritma sangat 
berperan penting dalam dunia komputer karena merupakan salah satu pembangun dari software [14].

Algoritma juga memiliki prosedur yang jelas dalam menyelesaikan suatu persoalan karena terdapat langkah-langkah dan jumlahnya juga terbatas. Penyajian algoritma dapat berupa gambar maupun pseudocode. Pseudocode merupakan kode pemrograman yang hampir sama dengan Pascal, ataupun $\mathrm{C}$, sehingga dapat digunakan untuk menggambarkan algoritma yang diinginkan oleh pemrogram. Untuk algoritma dalam bentuk gambar maka dapat disajikan dalam bentuk flowchart.

\subsection{Algoritma C4.5}

Algoritma C4.5 adalah suatu pengembangan induksi dari ID3 (Iterative Dichotomiser 3) karena C4.5 merupakan sebuah algoritma yang dapat digunakan untuk membuat sebuah pohon keputusan (decision tree). Pohon-pohon keputusan dibangun berdasarkan kriteria pembentuk suatu keputusan [15]. Pengembangan yang terdapat dalam C4.5 adalah dapat mengatasi nilai suatu atribut yang hilang (missing value), dapat mengolah data berjenis diskret maupun numerik, menghasilkan aturan yang mudah dalam pengintepretasian serta prunning atau pemangkasan [16].

Pemilihan atribut test untuk simpul, maka didasarkan pada atribut yang memiliki nilai Gain Ratio paling tinggi dari semua atribut yang ada. Tahapan untuk menghitung GainRatio dapat ditunjukkan menggunakan beberapa persamaan berikut [16] :

a. Tahapan pertama yaitu menghitung nilai Entropy dengan menggunakan rumus yang ditunjukkan oleh rumus (1) berikut ini.

Keterangan :

$$
\operatorname{Entropy}(S)=\sum_{i=1}^{n}-p i * \log _{2} p i
$$

$S:$ himpunan kasus

$\mathrm{n}$ : jumlah partisi hipunan $\mathrm{S}$

$\mathrm{Pi}$ : kasus partisi ke-i

b. Tahap kedua yaitu mencari nilai Gain dengan menggunakan rumus yang telah ditunjukkan pada persamaan (2) berikut.

$$
\operatorname{Gain}(\mathrm{S}, \mathrm{A})=\operatorname{Entropy}(\mathrm{S})-\sum_{i=1}^{n} \frac{|S i|}{|S|} * \operatorname{Entropy}(\mathrm{Si})
$$

Keterangan :

S : kasus

A : atribut

$\mathrm{n}:$ jumlah partisi atribut ke-A

$|\mathrm{Si}|$ : jumlah kasus partisi ke-i

$|\mathrm{S}|$ : jumlah kasus pada $\mathrm{S}$

c. Tahap ketiga yaitu menghitung Split Info dengan rumus yang ditunjukkan dalam persamaa (3) dibawah ini.

Keterangan :

$$
\operatorname{SplitInfo}(\mathrm{S}, \mathrm{A})=-\sum_{i=1}^{n} \frac{|S i|}{|S|} \log _{2} \frac{|S i|}{|S|}
$$

$\mathrm{S}=$ ruang sample data

$\mathrm{A}=$ atribut

$\mathrm{Si}=$ jumlah sample atribut ke-i

d. Tahap keempat yaitu mencari nilai Gain Ratio dengan menggunakan rumus seperti tertera dalam persamaan (4) berikut ini.

Keterangan :

$$
\operatorname{Gain} \operatorname{Ratio}(\mathrm{S}, \mathrm{A})=\frac{\operatorname{Gain}(S, A)}{\operatorname{SplitInfo}(S, A)}
$$

Gain $(\mathrm{S}, \mathrm{A})=$ informasi gain atribut $\mathrm{A}$

SplitInfo $(\mathrm{S}, \mathrm{A})=$ split informasi atribut $\mathrm{A}$

Jadi jika ada atribut yang memilki nilai Gain Ratio tertinggi, maka akan dipilih menjadi node sebagai atribut test simpul.

\subsection{Pohon Keputusan (Decission Tree)}

Saifur Rohman Cholil dkk: Prediksi Penyakit Demam Berdarah Di Puskesmas Ngemplak Simongan Menggunakan Algoritma C4.5 
Pohon keputusan merupakan suatu struktur yang mengklasifikasikan kumpulan data ke dalam tabel kelas yang telah ditentukan [17]. Tabel biasanya terdapat atribut yang berperan sebagai parameter dan record untuk membangun sebuah data. Manfaat menggunakan pohon keputusan adalah dapat mengubah sebuah fakta menjadi sebuah pohon keputusan yang lebih dapat dimengerti dan simpel dengan kombinasi bahasa alami. Pohon keputusan memiliki fungsi untuk menyelidiki data, mencari hubungan tersembunyi antara calon variabel target dengan variabel input yang akan digunakan. Perpaduan antara pemodelan dan eksplorasi data pada pohon keputusan sangat direkomendasikan sebagai langkah awal pemodelan serta model akhir dari beberapa teknik lain [7]. Simpul node dari decission tree pohon dibedakan menjadi tiga [11], yaitu :

a. Simpul akar (root node) yang letaknya berada pada bagian teratas serta tidak memiliki inputan namun terkadang memiliki output lebih dari satu atau tidak sama sekali.

b. Simpul percabangan ( internal node) yang hanya mempunyai satu inputan dan dua outputan minimal.

c. Simpul daun (leaf node) yang hanya mempunyai satu inputan dan sama sekali tidak memiliki outputan.

\section{METODE PENELITIAN}

Langkah yang digunakan pada penelitian ini untuk memprediksi penyakit DBD yang terdapat pada Puskesmas Ngemplak Simongan, yaitu dengan langkah KDD (Knowledge Discovery in Databases), yang telah terdapat beberapa tahapan yaitu seleksi, praproses, transformasi, data mining, interprestasi serta evaluasi.

\subsection{Jenis Data}

Penelitian ini meggunakan jenis data yang terdiri dari data kuantitatif dan data kualitatif. Data kuantitatif merupakan jenis data yang dapat dihitung dan berbentuk angka maupun bilangan, sedangkan data kualitatif merupakan data yang mengandung informasi dan berbentuk kalimat. Semua data yang ada diperoleh berasal dari data primer karena data yang dikumpulkan berasal dari narasumber pertama, yaitu Kepala Puskesmas Ngemplak Simongan.

\subsection{Tahapan Metodologi Penelitian}

\section{a. Pengumpulan Data}

Proses pengumpulan data merupakan mengumpulkan semua data yang diperlukan untuk mendukung proses algoritma C4.5. Semua data yang dibutuhkan dikumpulkan secara langsung dengan cara melakukan observasi di lapangan serta wawancara secara langsung dengan pihak terkait. Data primer yang digunakan adalah data yang berasal dari puskesmas yang berisi data pasien demam berdarah yang terdiri dari data training dan data testing.

b. Seleksi Data

Seleksi data merupakan proses menyortir atau memilih data-data yang akan dipergunakan dalam proses mining, namun tetap memperlihatkan bentuk data aslinya.

c. Transformasi Data

Transformasi data merupakan suatu cara untuk mengubah data asli ke bentuk lain agar dapat dilakukan pemrosesan dengan menggunakan algoritma C4.5.

d. Proses Perhitungan

Proses perhitungan untuk semua atribut maupun variable, entropy dapat menggunakan rumus (1), information gain dengan rumus (2), splitinfo menggunakan rumus (3), serta gainratio menggunakan rumus (4).

e. Decision Tree atau Pohon Keputusan

Pohon keputusan merupakan hasil dari perhitungan yang dilakukan sebelumnya, dengan dilakukannya perhitungan berulang kali hingga semua atribut memiliki kelas dan sudah tidak dapat lagi dilakukan perhitungan.

f. Pengujian

Tahap pengujian merupakan tahap pengetesan dimana hal ini dilajukan dengan tujuan untuk mengetahui semua proses dapat bekerja sesuai keinginan atau tidak.

Saifur Rohman Cholil dkk: Prediksi Penyakit Demam Berdarah Di Puskesmas Ngemplak Simongan Menggunakan Algoritma C4.5 
g. Analisis Hasil Pengujian

Tujuan dilakukannya proses analisis adalah untuk memastikan hasil uji benar-benar dapat dipertanggungjawabkan. Proses analisis dilakukan dengan cara menghitung kembali hasil pengujian secara manual dicocokkan dengan hasil perhitungan sistem.

\section{HASIL DAN PEMBAHASAN}

\subsection{Pengumpulan Data}

Pengumpulan data dilakukan dengan cara meminta data ke Puskesmas Ngemplak Simongan. Data yang diperlukan adalah data pasien penderita Demam Berdarah di Puskesmas Ngemplak Simongan yang diambil dari Kepala Sub Bagian (Kasubag) Kesehatan Masyarakat (Kesmas) Puskesmas Ngemplak Simongan. Adapaun bentuk datanya seperti pada Gambar 1.

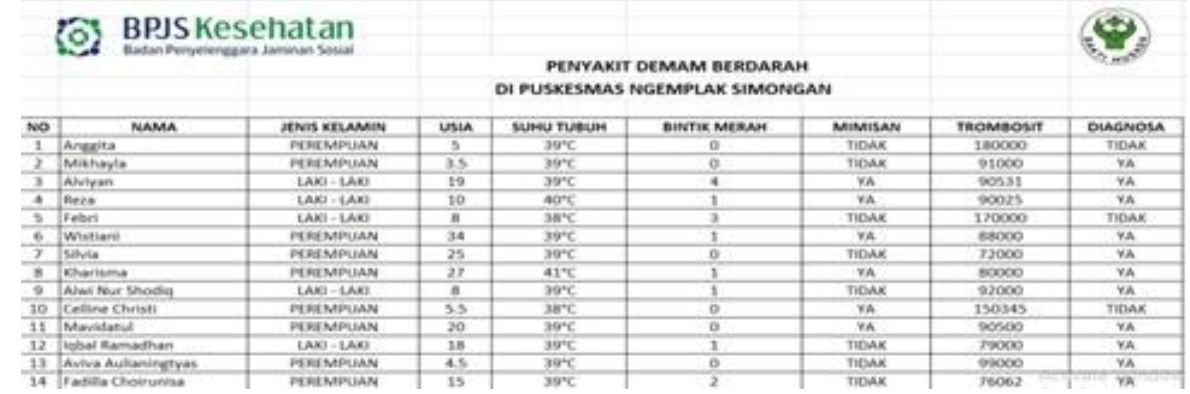

Gambar 1. Data Penyakit Demam Berdarah

\subsection{Seleksi Data}

Proses seleksi data dilakukan dengan cara memilih atribut atau variabel yang dibutuhkan. Pemilihan atribut dilakukan dengan pertimbangan atribut yang dipilih sudah sesuai dengan atribut yang dibutuhkan untuk melakukan proses prediksi demam berdarah. Dari data yang tersedia diambil beberapa atribut antara lain: suhu tubuh, bintik merah, mimisan, trombosit dan diagnosa.

\subsection{Transformasi Data}

Transformasi data dilakukan dengan cara mengubah data yang di dapat dari Puskesmas Ngemplak Simongan ke dalam format excel atau format CSV. Langkah ini dilakukan untuk analisis dan visualisasi data dengan aplikasi rapidminer.

\subsection{Proses Perhitungan Manual Metode Algoritma C4.5}

Adapun langkah perhitungan manual dengan menggunakan metode Algoritma C4.5 adalah mencari nilai dari entropy, gain, split info, dan gain ratio. Data yang diperoleh dari Kepala Sub Bagian (Kasubag) Kesehatan Masyarakat (Kesmas) Puskesmas Ngemplak Simongan yang telah dilakukan proses seleksi dan transformasi data seperti pada Tabel 1.

Langkah pertama yaitu menghitung nilai entropy. Perhitungan nilai entropy dilakukan sesuai dengan rumus persamaan 1 dan proses perhitungannya sebagai berikut :

Entropy $=\left(-\frac{28}{101} \times \log _{2} \frac{28}{101}\right)+\left(-\frac{73}{101} \times \log _{2} \frac{73}{101}\right)=0,8516$
Entropy $\left(38^{\circ} \mathrm{C}\right)=-\left(\frac{8}{26}\right) * \log 2\left(\frac{8}{26}\right)-\left(\frac{18}{26}\right) * \log 2\left(\frac{18}{26}\right)=0,8905$
Entropy $\left(39^{\circ} \mathrm{C}\right)=-\left(\frac{50}{59}\right) * \log 2\left(\frac{50}{59}\right)-\left(\frac{9}{59}\right) * \log 2\left(\frac{9}{59}\right)=0.6162$
Entropy $\left(40^{\circ} \mathrm{C}\right)=-\left(\frac{12}{13}\right) * \log 2\left(\frac{12}{13}\right)-\left(\frac{1}{13}\right) * \log 2\left(\frac{1}{13}\right)=0.3912$
Entropy $\left(41^{\circ} \mathrm{C}\right)=-\left(\frac{3}{3}\right) * \log 2\left(\frac{3}{3}\right)-\left(\frac{0}{3}\right) * \log 2\left(\frac{0}{3}\right)=0$

Analisa penyelesaian 1 node yaitu menghitung nilai total keputusan yang dinyatakan Ya (73) dan dinyatakan Tidak (28), sedangkan untuk jumlah 101 merupakan total dari seluruh data.

Langkah kedua yaitu menghitung nilai gain. Perhitungan ini sesuai dengan rumus persamaan 2 dan proses perhitungannya sebagai berikut :

Gain $=0,8516-\left(\left(\frac{26}{101} * 0,8905\right)+\left(\frac{59}{101} * 0,6162\right)+\left(\frac{13}{101} * 0,3912\right)+\left(\frac{3}{101} * 0\right)\right)=0,2121$

Langkah ketiga yaitu menghitung nilai split info. Perhitungan ini sesuai dengan rumus persamaan 3 dan proses perhitungannya sebagai berikut :

Split Info $=-\frac{26}{101} * \log 2\left(\frac{26}{101}\right)-\frac{59}{101} * \log 2\left(\frac{59}{101}\right)-\frac{13}{101} * \log 2\left(\frac{13}{101}\right)-\frac{3}{101} * \log 2\left(\frac{3}{101}\right)=1.4884$ 
Langkah keempat yaitu menghitung nilai gain ratio. Perhitungan ini sesuai dengan rumus persamaan 4 dan proses perhitungannya sebagai berikut :

$$
\text { Gain Ratio }=\frac{0,2121}{1,4884}=0,1425
$$

Tabel 1. Data Training

\begin{tabular}{|c|c|c|c|c|}
\hline Suhu Tubuh & Bintik Merah & Mimisan & Trombosit & Diagnosa \\
\hline $39^{\circ} \mathrm{C}$ & 0 & Tidak & resiko rendah & tidak \\
\hline $39^{\circ} \mathrm{C}$ & 0 & Tidak & resiko sedang & ya \\
\hline $39^{\circ} \mathrm{C}$ & 4 & $\mathrm{Ya}$ & resiko tinggi & ya \\
\hline $40^{\circ} \mathrm{C}$ & 1 & $\mathrm{Ya}$ & resiko tinggi & ya \\
\hline $38^{\circ} \mathrm{C}$ & 3 & Tidak & resiko rendah & tidak \\
\hline $39^{\circ} \mathrm{C}$ & 1 & $\mathrm{Ya}$ & resiko tinggi & ya \\
\hline $39^{\circ} \mathrm{C}$ & 0 & Tidak & resiko tinggi & ya \\
\hline $41^{\circ} \mathrm{C}$ & 1 & $\mathrm{Ya}$ & resiko tinggi & ya \\
\hline $39^{\circ} \mathrm{C}$ & 1 & Tidak & resiko sedang & ya \\
\hline $38^{\circ} \mathrm{C}$ & 0 & $\mathrm{Ya}$ & resiko rendah & tidak \\
\hline $39^{\circ} \mathrm{C}$ & 0 & $\mathrm{Ya}$ & resiko tinggi & ya \\
\hline $39^{\circ} \mathrm{C}$ & 0 & Tidak & resiko rendah & tidak \\
\hline $39^{\circ} \mathrm{C}$ & 0 & Tidak & resiko sedang & ya \\
\hline $39^{\circ} \mathrm{C}$ & 4 & $\mathrm{Ya}$ & resiko tinggi & ya \\
\hline $40^{\circ} \mathrm{C}$ & 1 & $\mathrm{Ya}$ & resiko tinggi & ya \\
\hline $38^{\circ} \mathrm{C}$ & 3 & Tidak & resiko rendah & tidak \\
\hline $39^{\circ} \mathrm{C}$ & 1 & $\mathrm{Ya}$ & resiko tinggi & ya \\
\hline $39^{\circ} \mathrm{C}$ & 0 & Tidak & resiko tinggi & ya \\
\hline $41^{\circ} \mathrm{C}$ & 1 & $\mathrm{Ya}$ & resiko tinggi & ya \\
\hline $39^{\circ} \mathrm{c}$ & 1 & Tidak & resiko tinggi & ya \\
\hline $39^{\circ} \mathrm{c}$ & 0 & Tidak & resiko sedang & ya \\
\hline $39^{\circ} \mathrm{c}$ & 2 & Tidak & resiko tinggi & ya \\
\hline $39^{\circ} \mathrm{c}$ & 0 & Tidak & resiko tinggi & ya \\
\hline $40^{\circ} \mathrm{c}$ & 2 & $\mathrm{Ya}$ & resiko tinggi & ya \\
\hline $40^{\circ} \mathrm{c}$ & 0 & $\mathrm{Ya}$ & resiko tinggi & ya \\
\hline $39^{\circ} \mathrm{c}$ & 0 & Tidak & resiko rendah & tidak \\
\hline $40^{\circ} \mathrm{c}$ & 1 & $\mathrm{Ya}$ & resiko tinggi & ya \\
\hline $39^{\circ} \mathrm{c}$ & 1 & $\mathrm{Ya}$ & resiko tinggi & ya \\
\hline $39^{\circ} \mathrm{c}$ & 0 & Tidak & resiko sedang & ya \\
\hline $39^{\circ} \mathrm{c}$ & 2 & Tidak & resiko tinggi & ya \\
\hline $38^{\circ} \mathrm{C}$ & 1 & $\mathrm{Ya}$ & resiko rendah & tidak \\
\hline $39^{\circ} \mathrm{c}$ & 0 & Tidak & resiko sedang & ya \\
\hline $41^{\circ} \mathrm{C}$ & 3 & $\mathrm{Ya}$ & resiko tinggi & ya \\
\hline $39^{\circ} \mathrm{c}$ & 1 & $\mathrm{Ya}$ & resiko tinggi & ya \\
\hline $39^{\circ} \mathrm{c}$ & 0 & $\mathrm{Ya}$ & resiko tinggi & ya \\
\hline $39^{\circ} \mathrm{c}$ & 4 & Tidak & resiko rendah & tidak \\
\hline $38^{\circ} \mathrm{c}$ & 0 & Tidak & resiko rendah & tidak \\
\hline $39^{\circ} \mathrm{c}$ & 0 & Tidak & resiko sedang & ya \\
\hline $38^{\circ} \mathrm{c}$ & 4 & $\mathrm{Ya}$ & resiko tinggi & ya \\
\hline $38^{\circ} \mathrm{c}$ & 7 & $\mathrm{Ya}$ & resiko tinggi & ya \\
\hline $39^{\circ} \mathrm{c}$ & 0 & $\mathrm{Ya}$ & resiko sedang & ya \\
\hline $39^{\circ} \mathrm{c}$ & 5 & Tidak & resiko tinggi & ya \\
\hline $39^{\circ} \mathrm{c}$ & 0 & Tidak & resiko sedang & ya \\
\hline $39^{\circ} \mathrm{c}$ & 0 & $\mathrm{Ya}$ & resiko sedang & ya \\
\hline $38^{\circ} \mathrm{c}$ & 0 & Tidak & resiko sedang & tidak \\
\hline $41^{\circ} \mathrm{C}$ & 2 & $\mathrm{Ya}$ & resiko tinggi & ya \\
\hline $39^{\circ} \mathrm{c}$ & 1 & $\mathrm{Ya}$ & resiko tinggi & ya \\
\hline $39^{\circ} \mathrm{c}$ & 0 & Tidak & resiko sedang & ya \\
\hline $39^{\circ} \mathrm{c}$ & 0 & Tidak & resiko rendah & tidak \\
\hline $39^{\circ} \mathrm{c}$ & 1 & $\mathrm{Ya}$ & resiko sedang & ya \\
\hline
\end{tabular}

Perhitungan suhu tubuh, bintik merah, mimisan dilakukan proses perhitungan seperti di atas dan hasil semua perhitungan seperti ditunjukkan pada Tabel 2.

Tabel 2. Penghitungan Node 1

\begin{tabular}{|c|c|c|c|c|c|c|c|c|c|}
\hline Node & Attribut & & $\begin{array}{l}\text { Total } \\
\text { data }\end{array}$ & $\mathrm{Ya}$ & Tidak & Entropy & Gain & $\begin{array}{l}\text { Split } \\
\text { info }\end{array}$ & $\begin{array}{l}\text { Gain } \\
\text { ratio }\end{array}$ \\
\hline \multirow[t]{21}{*}{1} & Diagnosa & & 101 & 73 & 28 & 0,8516 & & & \\
\hline & & & & & & & 0,2121 & 1,4884 & 0,1425 \\
\hline & Suhu tubuh & $38^{\circ} \mathrm{C}$ & 26 & 8 & 18 & 0,8905 & & & \\
\hline & & $39^{\circ} \mathrm{C}$ & 59 & 50 & 9 & 0,6162 & & & \\
\hline & & $40^{\circ} \mathrm{C}$ & 13 & 12 & 1 & 0,3912 & & & \\
\hline & & $41^{\circ} \mathrm{C}$ & 3 & 3 & 0 & 0 & & & \\
\hline & & & & & & & 0,06781 & 1,8461 & 0,0367 \\
\hline & $\begin{array}{l}\text { Bintik } \\
\text { merah }\end{array}$ & 0 & 56 & 35 & 21 & 0,9544 & & & \\
\hline & & 1 & 23 & 21 & 2 & 0,4262 & & & \\
\hline & & 2 & 9 & 7 & 2 & 0,7642 & & & \\
\hline & & 3 & 4 & 3 & 1 & 0,8113 & & & \\
\hline & & 4 & 6 & 4 & 2 & 0,9183 & & & \\
\hline & & 5 & 2 & 2 & 0 & 0 & & & \\
\hline & & 7 & 1 & 1 & 0 & 0 & & & \\
\hline & & & & & & & 0,0465 & 0,9982 & 0,0466 \\
\hline & $\begin{array}{l}\text { Mimisan } \\
\end{array}$ & Ya & 53 & 44 & 9 & 0,6573 & & & \\
\hline & & Tidak & 48 & 29 & 19 & 0,9685 & & & \\
\hline & & & & & & & 0,6706 & 1,5526 & 0,4319 \\
\hline & Trombosit & $\begin{array}{l}\text { Resiko } \\
\text { tinggi }\end{array}$ & 40 & 40 & 0 & 0 & & & \\
\hline & & $\begin{array}{l}\text { Resiko } \\
\text { sedang }\end{array}$ & 37 & 33 & 4 & 0.4942 & & & \\
\hline & & $\begin{array}{l}\text { Resiko } \\
\text { rendah }\end{array}$ & 24 & 0 & 4 & 0 & & & \\
\hline
\end{tabular}

Hasil dari Tabel 2, dapat diketahui bahwa nilai atribut dengan GainRatio paling tinggi adalah Saifur Rohman Cholil dkk: Prediksi Penyakit Demam Berdarah Di Puskesmas Ngemplak Simongan Menggunakan Algoritma C4.5 
Trombosit, yaitu sebesar 0,4319. Jadi dengan demikian Trombosit menjadi node akar. Adapun tiga atribut dari Trombosit yaitu Resiko Tinggi, Resiko Sedang dan Resiko Rendah. Dari ketiga nilai atribut tersebut, nilai Resiko Tinggi dan Resiko Rendah telah mengklasifikasikan permasalahan menjadi satu yaitu keputusan Tidak, sehingga tidak perlu dilakukan penghitungan lebih lanjut, namun untuk hasil nilai atribut Resiko Sedang masih perlu dilakukan penghitungan ulang. Perhitungan node ditunjukkan oleh Tabel 3 di bawah ini.

Tabel 3. Penghitungan Node 1.1

\begin{tabular}{|c|c|c|c|c|c|c|c|c|c|}
\hline Node & Attribut & & $\begin{array}{l}\text { Total } \\
\text { data }\end{array}$ & $\mathrm{Ya}$ & Tidak & Entropy & Gain & $\begin{array}{l}\text { Split } \\
\text { info }\end{array}$ & $\begin{array}{l}\text { Gain } \\
\text { ratio }\end{array}$ \\
\hline \multirow[t]{15}{*}{1.1} & $\begin{array}{c}\text { Trombosit } \\
\text { resiko } \\
\text { sedang } \\
\end{array}$ & & 37 & 33 & 4 & 0.4942 & & & \\
\hline & Subutwh & $38^{\circ} \mathrm{C}$ & 7 & 3 & 4 & 0.9852 & 0,1382 & 0,8707 & 0,1587 \\
\hline & & $39^{\circ} \mathrm{C}$ & 29 & 28 & $\frac{7}{1}$ & $\begin{array}{l}0,2164 \\
0,2164\end{array}$ & & & \\
\hline & & $40^{\circ} \mathrm{C}$ & 1 & 1 & 0 & 0 & & & \\
\hline & & $41^{\circ} \mathrm{C}$ & 0 & 0 & 0 & 0 & & & \\
\hline & & & & & & & 0,0656 & 1,0331 & 0,0635 \\
\hline & $\begin{array}{l}\text { Bintik } \\
\text { merah }\end{array}$ & 0 & 25 & 21 & 4 & 0,6243 & & & \\
\hline & & 1 & 10 & 10 & 0 & 0 & & & \\
\hline & & 2 & 0 & 0 & 0 & 0 & & & \\
\hline & & 3 & 1 & 1 & 0 & 0 & & & \\
\hline & & 4 & 0 & 0 & 0 & 0 & & & \\
\hline & & $\frac{5}{7}$ & 0 & 0 & 0 & 0 & & & \\
\hline & & 7 & 0 & 0 & 0 & 0 & 01077 & 180257 & 0,1050 \\
\hline & Mimisan & Ya & 17 & 16 & 1 & 0,3228 & & & \\
\hline & & Tidak & 10 & 7 & 3 & 0,8813 & & & \\
\hline
\end{tabular}

Jika dilihat dari Tabel 3, maka dapat disimpulkan bahwa nilai atribut dengan GainRatio paling tinggi adalah Suhu Tubuh, yaitu sebesar 0,1587. Maka, Suhu Tubuh dapat dijadikan sebagai node cabang dari nilai atribut sebesar $38^{\circ} \mathrm{C}$ atau Sedang. Terdapat empat nilai atribut dari Suhu Tubuh, yaitu $38^{\circ} \mathrm{C}, 39^{\circ} \mathrm{C}, 40^{\circ} \mathrm{C}$ dan $41^{\circ} \mathrm{C}$. Dari keempat nilai atribut tersebut, nilai atribut $39^{\circ} \mathrm{C}$, $40^{\circ} \mathrm{C}$ dan $41^{\circ} \mathrm{C}$ atau Tinggi telah digolongkan kasus menjadi 1 , yaitu keputusan YA, dan nilai atribut Tinggi sudah mengklasifikasikan kasus menjadi 1, yaitu keputusan YA, maka tidak perlu dilakukan penghitungan ke tahap selanjutya, namun untuk nilai atribut $38^{\circ} \mathrm{C}$ atau Sedang masih perlu dilakukan penghitungan lagi. Perhitungan node berikutnya ditunjukkan oleh Tabel 4.

Tabel 4. Penghitungan Node 1.1.2

\begin{tabular}{|c|c|c|c|c|c|c|c|c|c|}
\hline Node & Attribut & & $\begin{array}{c}\text { Total } \\
\text { data }\end{array}$ & Ya & Tidak & Entropy & Gain & $\begin{array}{l}\text { Split } \\
\text { info }\end{array}$ & $\begin{array}{l}\text { Gain } \\
\text { ratio }\end{array}$ \\
\hline \multirow[t]{12}{*}{1.1 .2} & $\begin{array}{c}\text { Trombosit } \\
\text { resiko } \\
\text { sedang } \\
\text { dan Suhu } \\
\text { Tubuh } 38^{\circ} \mathrm{C} \\
\end{array}$ & & 7 & 3 & 4 & 0.9852 & & & \\
\hline & & & & & & & 0,2917 & 0,7478 & 0,3901 \\
\hline & $\begin{array}{l}\text { Bintik } \\
\text { merah }\end{array}$ & 0 & 5 & 2 & 3 & 0,9710 & & & \\
\hline & & 1 & 0 & 0 & 0 & 0 & & & \\
\hline & & 2 & 1 & 1 & 0 & 0 & & & \\
\hline & & 3 & 1 & 1 & 0 & 0 & & & \\
\hline & & 4 & 0 & 0 & 0 & 0 & & & \\
\hline & & 5 & 0 & 0 & 0 & 0 & & & \\
\hline & & 7 & 0 & 0 & 0 & 0 & & & \\
\hline & & & & & & & 0,1281 & 0,9852 & 0,1300 \\
\hline & Mimisan & Ya & 4 & 3 & 1 & 0,8183 & & & \\
\hline & & $\begin{array}{l}\text { Tidak } \\
\end{array}$ & 3 & 1 & 2 & 0,9183 & & & \\
\hline
\end{tabular}

Kesimpulan yang dapat diambil dari Table 4 adalah bahwa atribut dengan nilai GainRatio paling tinggi adalah Bintik Merah, yaitu sebesar 0,3901. Sehingga Bintik Merah dapat dijadikan sebagai node cabang dari nilai atribut Suhu Tubuh. Terdapat empat nilai atribut dari Bintik Merah, 0,1,2,3,4,5 dan 7. Dari keenam nilai atribut tersebut nilai atribut 1,2,3,4,5,7 telah mengklasifikasikan suatu kasus menjadi 1, yaitu keputusan YA, namun untuk nilai atribut $\mathbf{0}$ masih diperlukan penghitungan ulang kembali. Perhitungan node berikutnya ditunjukkan oleh Tabel 5 .

Tabel 5. Penghitungan Node 1.1.3

\begin{tabular}{|c|c|c|c|c|c|c|c|c|c|}
\hline Node & Attribut & & $\begin{array}{l}\text { Total } \\
\text { data }\end{array}$ & Ya & Tidak & Entropy & Gain & $\begin{array}{l}\text { Split } \\
\text { info }\end{array}$ & $\begin{array}{l}\text { Gain } \\
\text { ratio }\end{array}$ \\
\hline \multirow[t]{4}{*}{ 1.1.2 } & $\begin{array}{c}\text { Trombosit } \\
\text { Resiko } \\
\text { Sedang } \\
\text { dan Suhu } \\
\text { Tubuh } 38^{\circ} \mathrm{C} \\
\text { dan Bintik } \\
\text { Merah "0" }\end{array}$ & & 5 & 2 & 3 & 0.99710 & & & \\
\hline & & & & & & & 0,4200 & 0,9710 & 0,4325 \\
\hline & Mimisan & Ya & 3 & 2 & 1 & 0,9183 & & & \\
\hline & & Tidak & 2 & 0 & 2 & 0 & & & \\
\hline
\end{tabular}


Dari Tabel 5, telah diketahui bahwa atribut dengan GainRatio dari Mimisan, yaitu sebesar 0,4325 dan nilai opsi atribut dari Mimisan, yaitu YA dan TIDAK. Dari kedua jumlah nilai atribut tersebut, maka nilai atribut TIDAK telah digolongkan kasus menjadi 1, yaitu berupa keputusan Tidak, serta nilai untuk nilai atribut YA telah menggolongkan kasus menjadi 1 dengan keputusan Ya, jadi tidak diperlukan penghitungan ke tahap selanjutnya untuk jenis atribut tersebut.

\subsection{Desain Sistem}

Input Data Training, dalam tahap ini software yang digunakan adalah Rapid Miner. Langkah- langkahnya antara lain sebagai berikut :

a. Read Excel

Read excel digunakan untuk membaca data dari format microsoft excel. Data yang sudah ada ke dalam aplikasi rapidminer. Tampilannya ditunjukkan oleh Gambar 2.

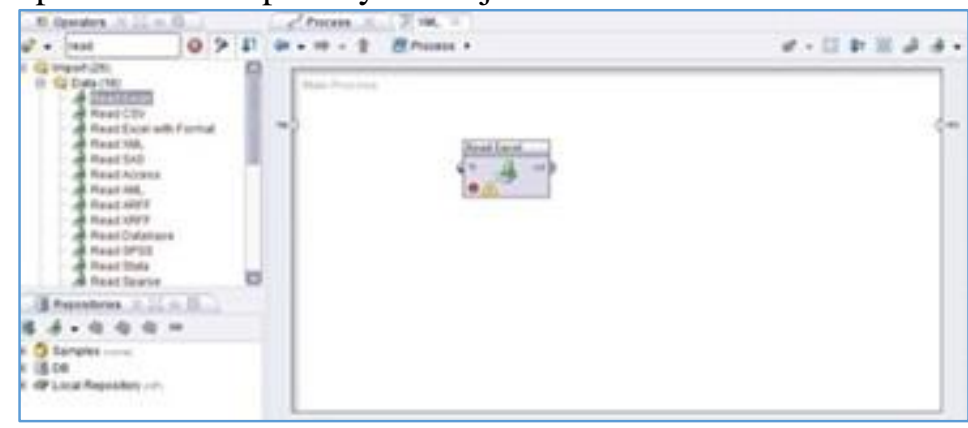

Gambar 2. Read Excel

Pada Gambar 2 di atas dijelaskan tentang langkah pertama pada desain sistem menggunakan aplikasi rapidminer, pada tahap ini menambahkan operator read excel yang digunakan untuk membaca data dari file microsoft excel.

\section{b. Import Configuration Wizard}

Tahapan berikutnya ada import configuration wizard yang ditunjukkan oleh Gambar 3.

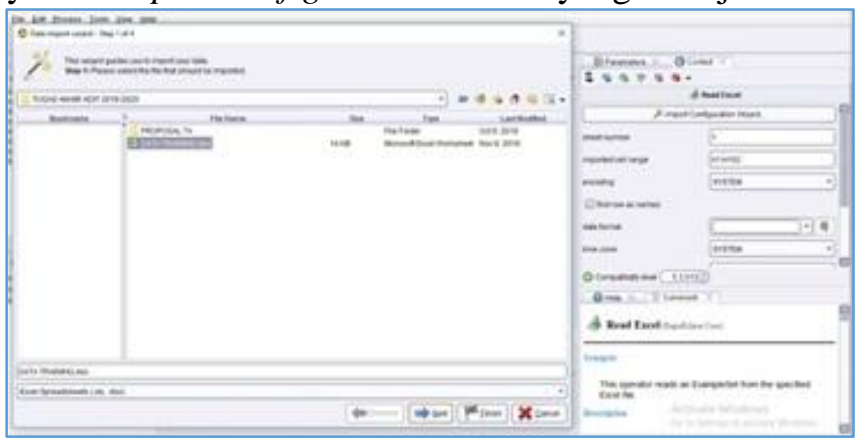

Gambar 3. Tampilan Import Configuraion Wizard

Gambar 3 menjelaskan tentang cara mengimport file excel untuk disesuaikan formatnya dengan format rapidminer. Pada bagian sebelah kanan kemudian pilih file dataset yang sudah siap kemudian pilih Next.

\section{c. Blok kolom yang diperlukan}

Langkah ketiga adalah memblok kolom yang akan digunakan dalam pembentukan model serperti ditunjukkah oleh Gambar 4. 


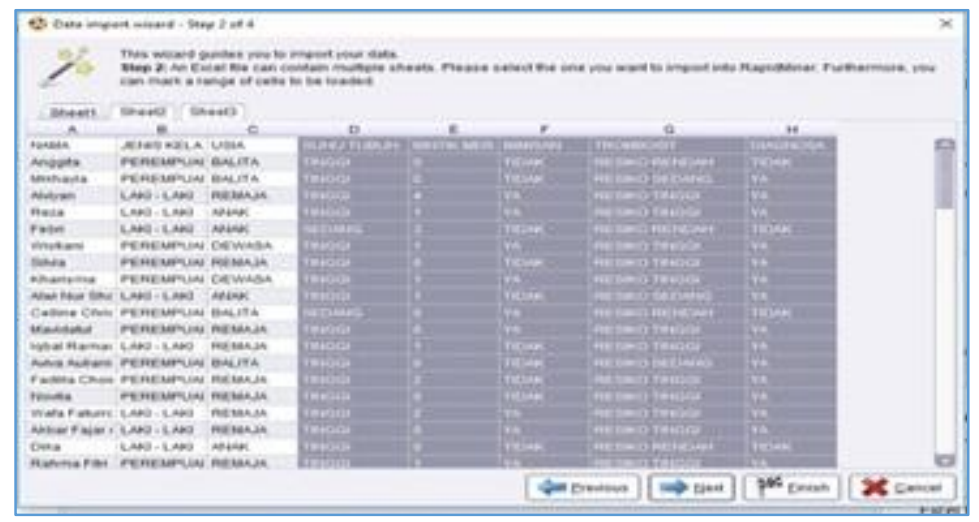

Gambar 4. Blok Kolom Yang Diperlukan

Gambar 4 di atas menjelaskan tentang memilih kolom yang diperlukan untuk keperluan analisis data.

\section{d. Penentuan jenis atribut}

Berikutnya adalah penentuaan jenis atribut seperti pada Gambar 5 di bawah ini.

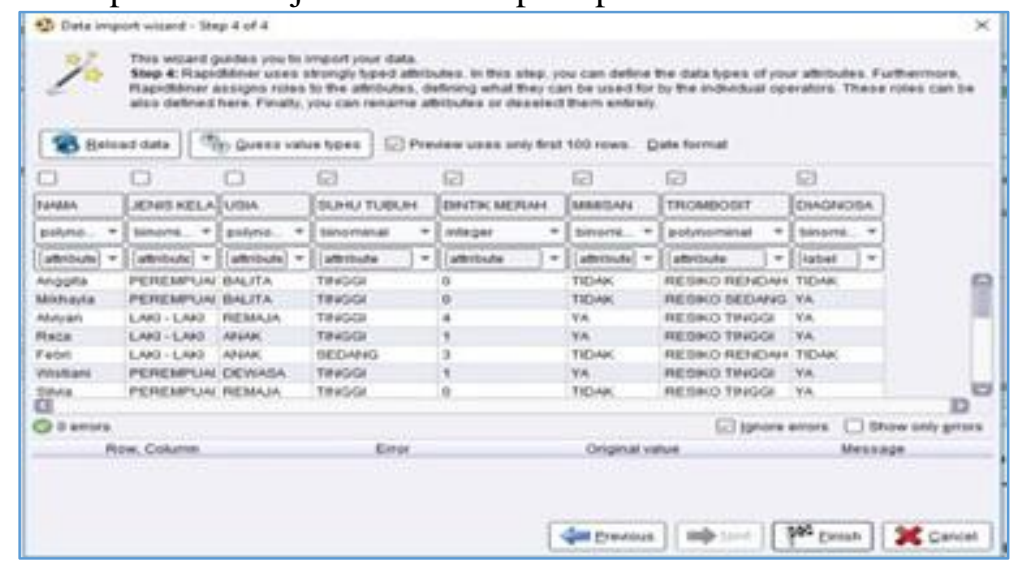

Gambar 5. Penentuan Jenis Atribut

Gambar 5 di atas menjelaskan tentang penentuan jenis atribut. Pada tahap ini memilih atribut seperti pada pada penjelasan di bawah ini.

Tahap terakhir dalam Read Excel adalah penentuan jenis atribut deskripsinya sebagai berikut :

(1) Suhu Tubuh $=$ Binominal dan Atribut

(2) Bintik Merah = Integer dan Atribut

(3) Mimisan $=$ Binominal dan Atribut

(4) Trombosit $=$ Polynominal dan Atribut

(5) Diagnosa $=$ Binominal dan Label

\subsection{Pembentukan Hasil Decision Tree}

Hasil dari perhitungan node didapatkan decision tree seperti Gambar 6. Gambar 6 di atas menjelaskan pohon keputusan yang didapatkan dari hasil perhtitungan node. Tahap ini merupakan tahap penghitungan manual secara keseluruhan dan hasil nilai dari pengujian data set yang telah dilakukan melalui aplikasi rapidminer. 


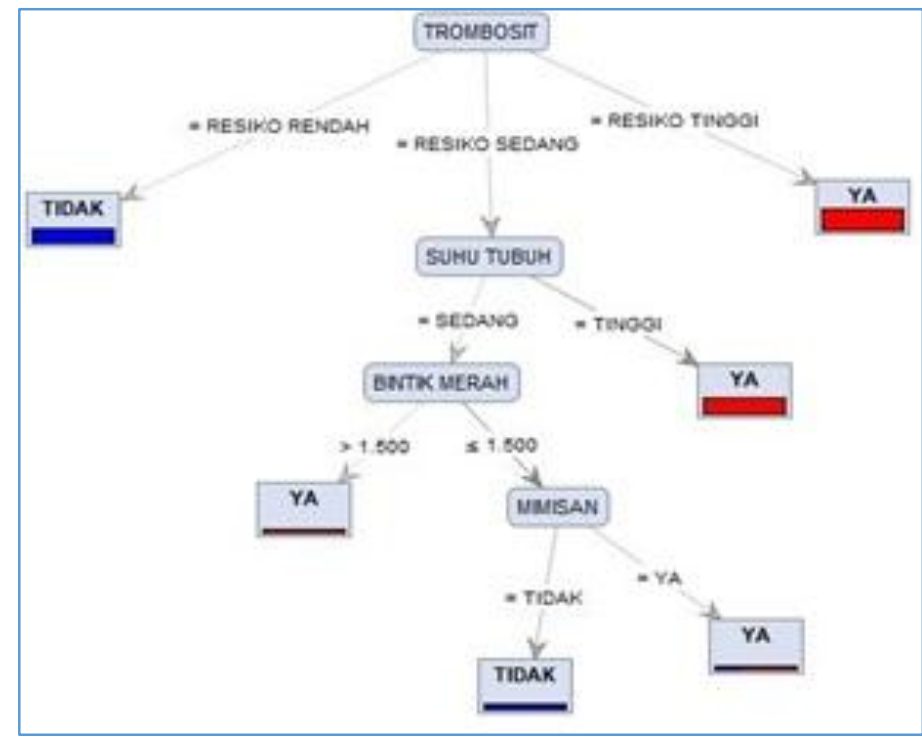

Gambar 6. Decision Tree

Selanjutnya hasil dari pohon keputusan diatas akan diekstraksi menjadi rule-rule seperti pada Tabel 6 berikut ini.

\begin{tabular}{cl}
\multicolumn{1}{c}{ Tabel 6 Rule } \\
\hline Id & \multicolumn{1}{c}{ Rule } \\
\hline 1 & If Trombosit = Resiko Tinggi Then Diagnosa = YA \\
\hline 2 & If Trombosit = Resiko Sedang And Suhu Tubuh = Tinggi Then Diagnosa = YA \\
\hline 3 & If Trombosit = Resiko Sedang And Suhu Tubuh = Sedang And Bintik Merah $=\leq 1.500$ \\
& And Mimisan = Ya Then Diagnosa = YA \\
\hline 4 & If Trombosit = Resiko Sedang And Suhu Tubuh = Sedang And Bintik Merah $=\leq 1.500$ \\
& And Mimisan = Tidak Then Diagnosa = TIDAK \\
\hline 5 & If Trombosit = Resiko Sedang And Suhu Tubuh = Sedang And Bintik Merah $=>1.500$ \\
& Then Diagnosa = YA \\
\hline 6 & If Trombosit = Resiko Rendah Then Diagnosa = TIDAK \\
\hline
\end{tabular}

\subsection{Pengujian Data dan Analisis Hasil Pengujian}

Hasil dari perhitungan data testing ditunjukkan oleh Gambar 7 dan hasil akurasi ditunjukkan oleh Gambar 8.

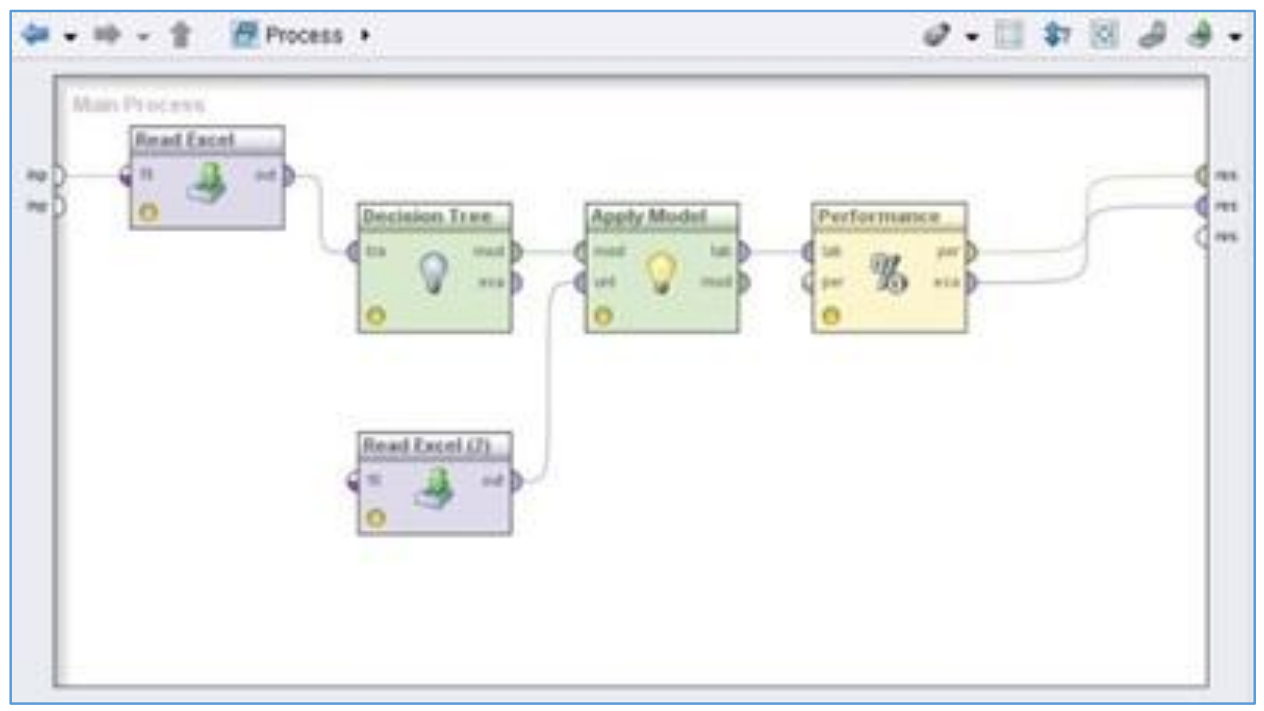

\section{Gambar 7. Pengujian Data Testing Pada Rapid Miner}




\begin{tabular}{|c|c|c|c|}
\hline \multicolumn{4}{|c|}{ - Tasle Vere O plativen } \\
\hline \multicolumn{4}{|c|}{ accuracysesess } \\
\hline & tonta & twe Todx & dass procision \\
\hline gen YA & 23 & o & $10000 \mathrm{k}$ \\
\hline gend rox & 2 & 11 & $8652 \%$ \\
\hline Gitine? & 192000 & 1000008 & \\
\hline
\end{tabular}

Gambar 8. Hasil Akurasi Pengujian Data Training Pada Rapid Miner

Pada Gambar 7 di atas menunjukkan tahap pengujian data testing pada rapidminer bertujuan mengetahui hasil akurasi algoritma $\mathrm{C} 4.5$ pada prediksi pasien demam berdarah di Puskesmas Ngemplak Simongan. Gambar 8 menunjukkan analisis hasil pengujian data pasien demam berdarah puskesmas Ngemplak Simongan pada rapidminer menggunakan algoritma C4.5 memiliki akurasi yaitu $94.44 \%$.

Hasil pembentukan decision tree dalam bentuk description ditunjukkah oleh Gambar 9.

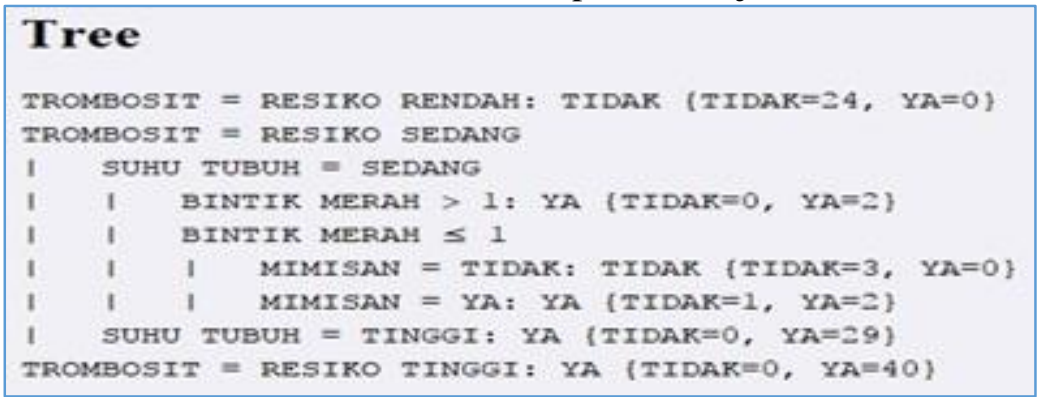

\section{Gambar 9. Deskripsi Tree}

Gambar 9 di atas menunjukkan diskiripsi dalam bentuk kalimat dari pohon keputusan dan menunjukkan hasil akhir dari penggunan algoritma C4.5.

\subsection{Hasil}

Setelah melakukan penghitungan untuk mendapatkan nilai-nilai entropy, gain, splitinfo, dan gainratio, kemudian hasil penghitungan tersebut diaplikasikan menggunakan bahasa pemrogaman berbasis web yaitu PHP (Hypertext Preprocessor). Berikut tampilan halaman utama Sistem Informasi Prediksi Penyakit Demam Berdarah dapat ditunjukkan pada Gambar 10.

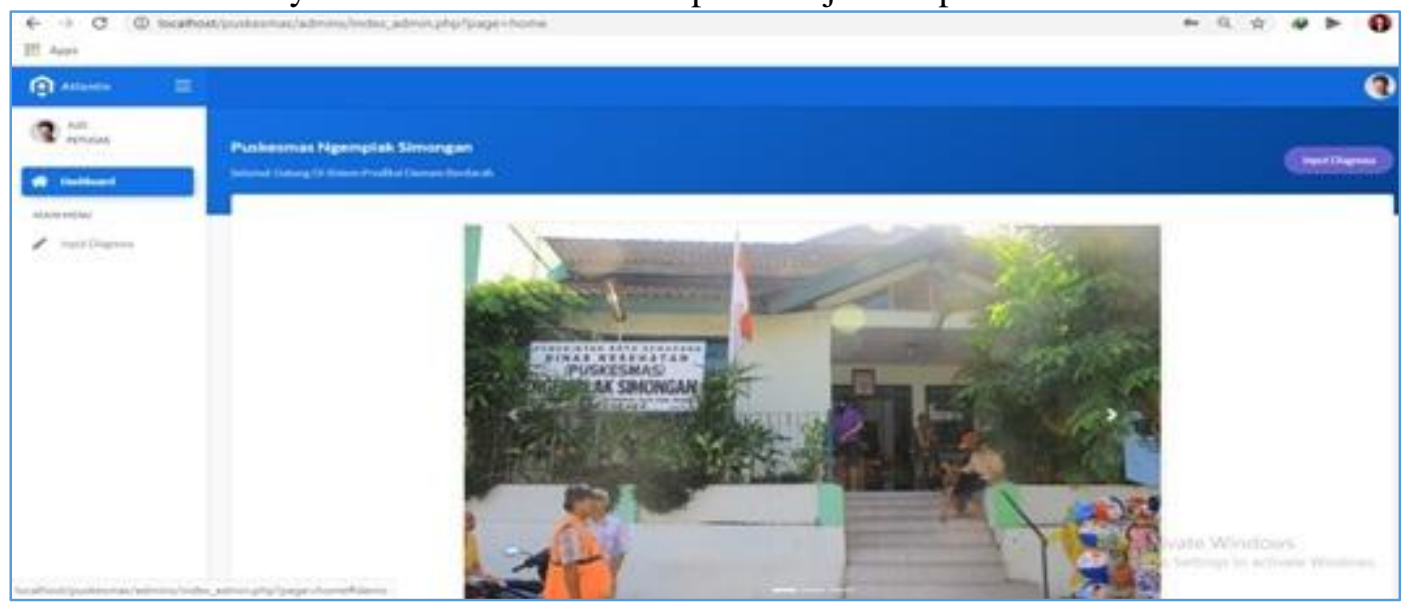

Gambar 10. Tampilan Halaman Utama Sistem Informasi Prediksi Penyakit DBD

Tampilan halaman utama program di atas terdapat pilihan untuk melakukan input diagnosa, disini petugas dapat mengelola sistem dengan menambah atau menginput data pasien baru. Halaman kelola data pasien ditunjukkah oleh Gambar 11. 


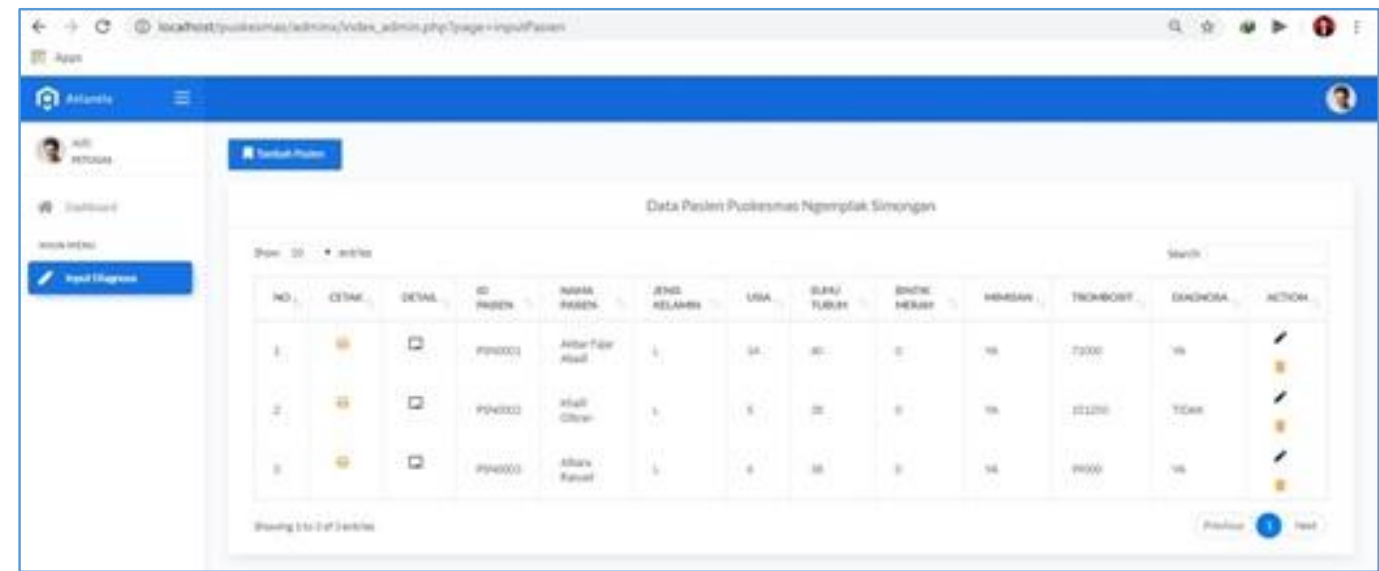

Gambar 11. Tampilan Halaman Kelola Data Pasien

Pada Gambar 11 di atas menampilkan data pasien yang telah diinputkan oleh petugas, yang kemudian data akan langsung tersimpan otomatis ke dalam database. Terdapat pilihan untuk melakukan tambah, edit, hapus, detail dan cetak data pasien. Tampilan prediksi pasien demam berdarah ditunjukkan oleh Gambar 12 dan Gambar 13.
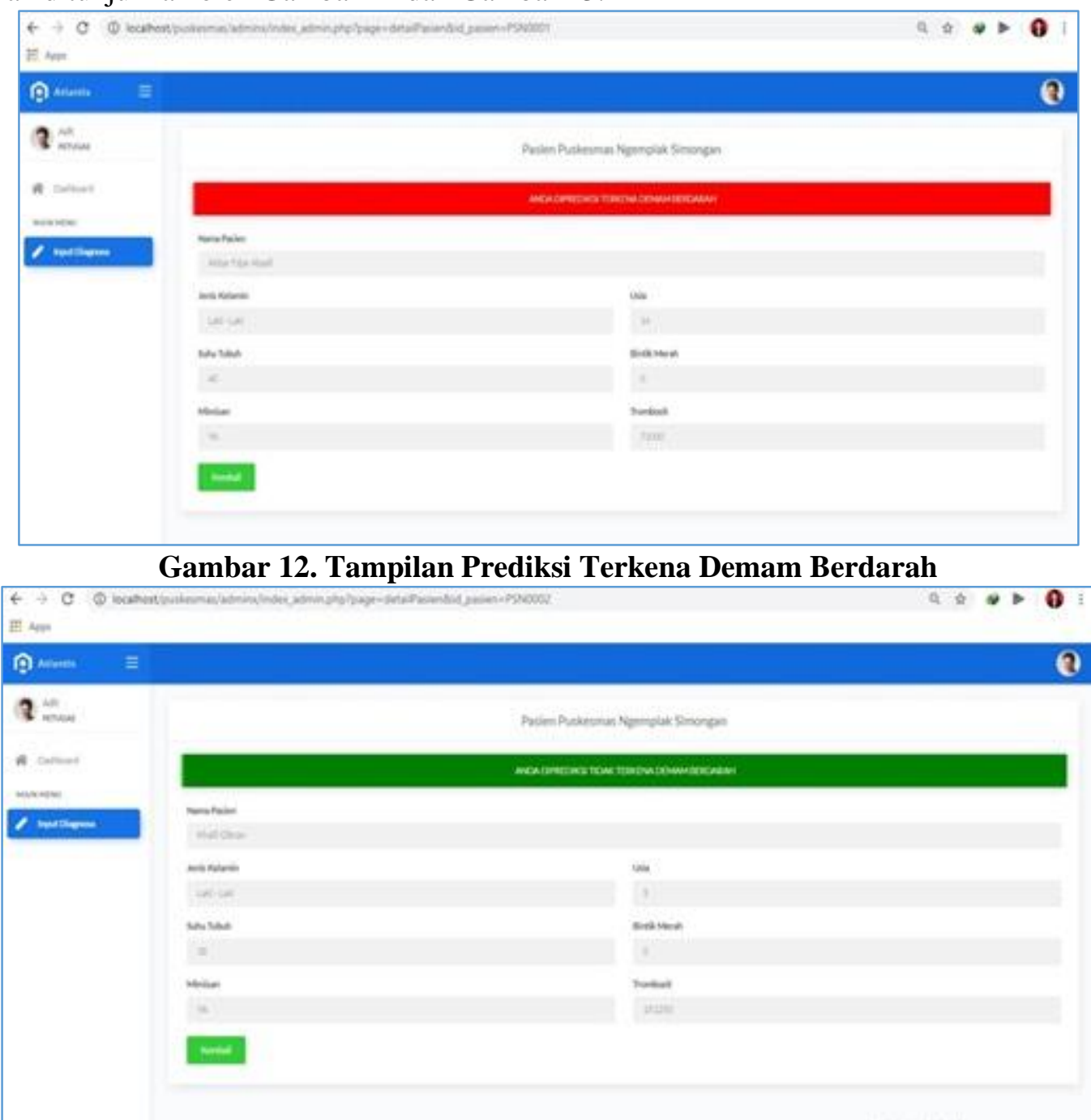

Gambar 13. Tampilan Prediksi Tidak Terkena Demam Berdarah 
Beberapa kode program untuk implementasi untuk implementasi algoritma C4.5 pada aplikasi di atas adalah sebagai berikut :

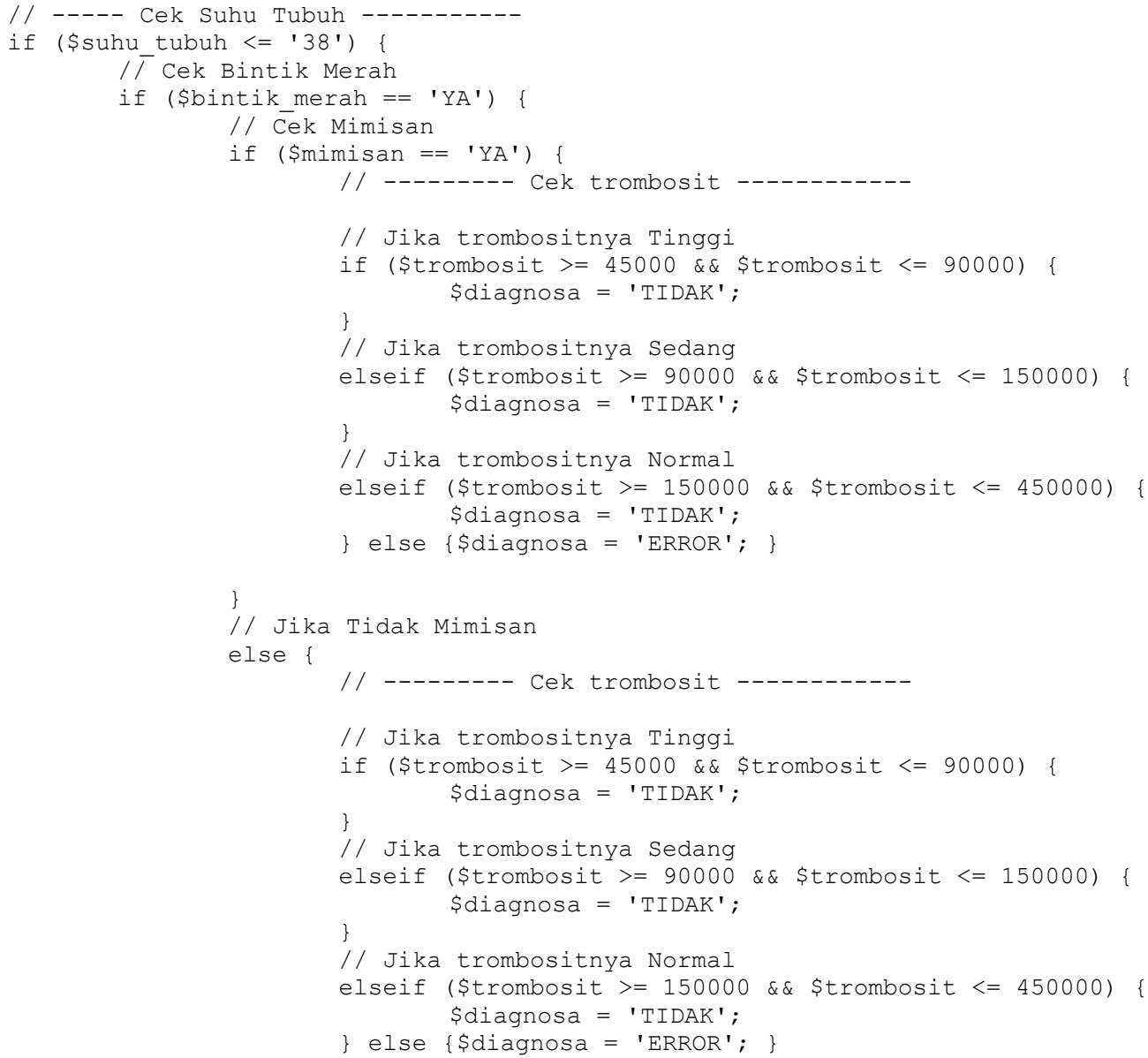

\section{KESIMPULAN}

Berdasarkan pembahasan yang telah dijelaskan, maka dapat ditarik kesimpulan bahwa implementasi model berupa aplikasi pengujian adalah prediksi penyakit demam berdarah. Setelah petugas menginputkan nilai suhu tubuh, bintik merah, mimisan dan trombosit maka akan diperoleh nilai akurasi sebesar $94.44 \%$ sehingga aplikasi program yang dibangun dapat digunakan secara benar dan dapat dipertanggungjawabkan. Masukan dan pertimbangan pada aplikasi ini dapat lebih berintegrasi dengan sistem rekam medis dengan Rumah Sakit (rujukan) dan dapat dikembangkan dengan algoritma lain dalam data mining seperti Naïve Bayes, KNN dan lain-lain.

\section{REFERENSI}

[1] S. Sundaramurthy and P. Jayavel, "A hybrid Grey Wolf Optimization and Particle Swarm Optimization with C4.5 approach for prediction of Rheumatoid Arthritis," Appl. Soft Comput. J., vol. 94, pp. 1-11, 2020.

[2] K. R. Pradeep and N. C. Naveen, "Lung Cancer Survivability Prediction based on Performance Using Classification Techniques of Support Vector Machines, C4.5 and Naive Bayes Algorithms for Healthcare Analytics," Procedia Comput. Sci., vol. 132, pp. 412-420, 2018.

[3] A. Joshuva, R. S. Kumar, S. Sivakumar, G. Deenadayalan, and R. Vishnuvardhan, "An insight on VMD for diagnosing wind turbine blade faults using $\mathrm{C} 4.5$ as feature selection and discriminating through multilayer perceptron," Alexandria Eng. J., pp. 1-17, 2020.

[4] R. Benkercha and S. Moulahoum, "Fault detection and diagnosis based on C4.5 decision tree algorithm for grid connected PV system," Sol. Energy, vol. 173, no. April, pp. 610-634, 2018.

Saifur Rohman Cholil dkk: Prediksi Penyakit Demam Berdarah Di Puskesmas Ngemplak Simongan Menggunakan Algoritma C4.5 
[5] L. Han, W. Li, and Z. Su, "An assertive reasoning method for emergency response management based on knowledge elements C4.5 decision tree," Expert Syst. Appl., vol. 122, pp. 65-74, 2019.

[6] P. Kudła and T. P. Pawlak, "One-class synthesis of constraints for Mixed-Integer Linear Programming with C4.5 decision trees," Appl. Soft Comput. J., vol. 68, pp. 1-12, 2018.

[7] I. D. Mienye, Y. Sun, and Z. Wang, "Prediction performance of improved decision treebased algorithms: A review," Procedia Manuf., vol. 35, pp. 698-703, 2019.

[8] X. Meng, P. Zhang, Y. Xu, and H. Xie, "Construction of decision tree based on C4.5 algorithm for online voltage stability assessment," Int. J. Electr. Power Energy Syst., vol. 118, no. December 2019, pp. 1-8, 2020.

[9] E. Ermawati, "Algoritma Klasifikasi C4.5 Berbasis Particle Swarm Optimization Untuk Prediksi Penerima Bantuan Pangan Non Tunai," vol. 8, no. September, pp. 513-528, 2019.

[10] N. Azwanti and E. Elisa, "Analisis Pola Penyakit Hipertensi Menggunakan Algoritma C4 . 5," vol. 2, 2019.

[11] J. Eska, "Penerapan Data Mining Untuk Prekdiksi Penjualan Wallpaper Menggunakan Algoritma C4.5 STMIK Royal Ksiaran,” JURTEKSI (Jurnal Teknol. dan Sist. Informasi), vol. 2, pp. 9-13, 2016.

[12] S. Haryati, A. Sudarsono, and E. (2015) Suryana, "Implementasi Data Mining untuk Memprediksi Masa Studi Mahasiswa Menggunakan Algoritma C4.5," J. Media Infotama, vol. 11, no. 2, pp. 130-138, 2015.

[13] R. Nofitri and N. Irawati, "Analisis Data Hasil Keuntungan Menggunakan Software Rapidminer," vol. V, no. 2, pp. 199-204, 2019.

[14] G. G. Maulana, "Pembelajaran Dasar Algoritma Dan Pemrograman Menggunakan ElGoritma Berbasis Web," J. Tek. Mesin, vol. 6, no. 2, p. 8, 2017.

[15] T. Tukino, "Penerapan Algoritma C4.5 Untuk Memprediksi Keuntungan Pada PT SMOE Indonesia," J. Sist. Inf. Bisnis, vol. 9, no. 1, p. 39, 2019.

[16] F. F. Harryanto and S. Hansun, "Penerapan Algoritma C4.5 untuk Memprediksi Penerimaan Calon Pegawai Baru di PT WISE," J. Tek. Inform. Dan Sist. Inf., vol. 3, no. 2, pp. 95-103, 2017.

[17] A. Syafnur, "Analisis Dengan Metode Klasifikasi Menggunakan Decission Tree Untuk Memprediksi Penentuan Resiko Kredit Bank,” vol. IV, no. 1, 2017. 